\title{
The quality of surface water in Salekhard
}

\author{
Yulia Pechkina ${ }^{*}$, Elena Shinkaruk, Roman Kolesnikov, Aleksandr Krasnenko and Elena \\ Agbalyan \\ Arctic Research Center of the Yamal-Nenets Autonomous District, 629000 Salekhard, Russian
}

\begin{abstract}
The work includes the natural waters' quality control within the precincts of Salekhard. Shaytanka River, Poluy River and Lebyazhye Lake were discovered. By waters' quality control was used pollution index. The work is done in terms of Scientific work (NIR) "Assessment of the health risk of the population of the Yamalo-Nenets Autonomous District in connection with the impact of chemical environmental factors".
\end{abstract}

\section{Introduction}

The self-purification of the Western Siberia's Rivers is usually lower than in the European part of Russia [1]. The Problem of quality of surface water's recourses and its self-purification is important and can be an indicator ecological situation, especially near withdrawal point. The water collections of headwater are indicators of landscape. The anthropogenic factor influences on the chemical constitution of rivers, which is closely related to dynamic commercial development of Yamal-Nenets Autonomous District. The Concentration of oil-products, metals and synthetically surfactants is increased in the rivers of Yamal-Nenets Autonomous District. The surface water's quality is depended on level of cleaning of discharged waters of factories. The Concentration of oil-products, phenols, heavy-metal ions, organic and biogenous materials in bodies of water is increased along anthropogenic activities [2]. The microorganisms are important and dominating part of food chain according to modern presentation of trophic dynamics. The basin's steadfast development of medium-width rivers and headwaters is a key component of regions' development.

The working purpose is to give an appraisal of condition of Salekhard's water reservoir in Yamal-Nenets Autonomous District.

\section{Materials and methods}

The samples of natural waters were taken from Lebyazhye lake, Shaytanka river, Poluy river within the precincts of Salekhard (Fig. 1.) according to GOST 31861-2021 "Water. A general requirement of sample's taking".

\footnotetext{
*Corresponding author: pechkinagis@gmail.com
} 


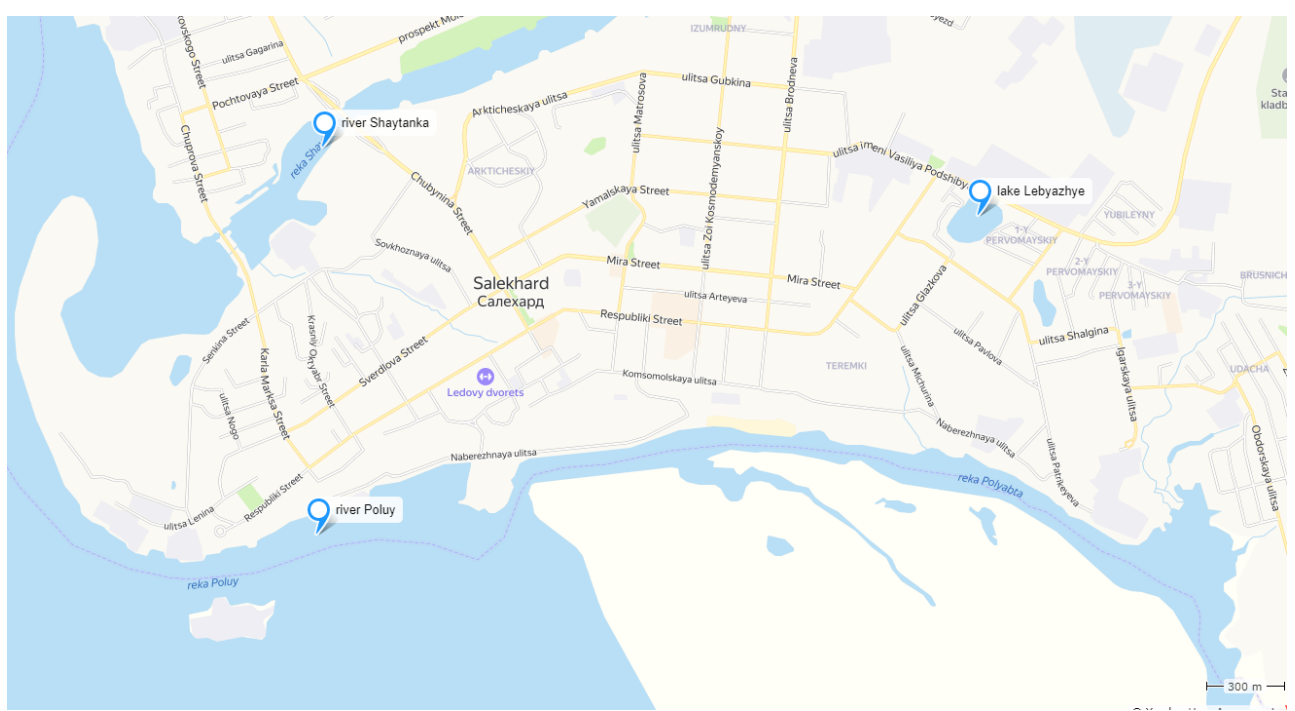

Fig. 1. Scheme of sample's taking within the precincts of Salekhard.

The researchers of water samples are done on the basis of chemical analysis laboratory of State Public Institution "The Arctic Research Centre" according to methods, which are accepted to make measurements, which have application to State Metrological Control's range of influence. Elementary analysis of water sample is done in Analytical Certification testing center by Federal State Budgetary Institution of Science Institute for Problems of Microelectronics Technology and High Purity Materials.

The natural water's quality was estimated according to regulation of maximum allowable concentration (MAC) of repugnant substance in fishery water bodies and medium local relevance of surface water of the Priuralsky district [3]. In samples of surface water were specified the following estimates such as color index, turbidity, clarity, specific electrical conduction (sec), $\mathrm{pH}$, alkalinity, self-scaling capability, stuffs of biogenic substances (ammoniacal group, phosphates), chemical oxygen demand, oil products, metals and metalloid ( $\mathrm{Mg}, \mathrm{Mn}, \mathrm{Fe}, \mathrm{Ni}, \mathrm{As}, \mathrm{Al}, \mathrm{Be}, \mathrm{Ba}, \mathrm{Hg}, \mathrm{Cu}, \mathrm{Pb}, \mathrm{Zn})$. The definition of specific combinatorial index of water contamination rate and degree of quality is done according to directive document (RD 52.24.643 2002).

\section{Results and discussion}

The anthropogenic effect always influences on water bodies because of locating in the city boundary. Poluy River is formed by merge of the Glubokiy Poluy and Sukhoy Poluy and flowed into the river $\mathrm{Ob}$ on the right side by Salekhard. Shaytanka River is a tributary of the Poluy River and starts in the fennish area to the east of the city and within the ambit of Priuralsky region. Lebyazhye Lake is located in the Salekhard's eastern part. Nowadays it is making an upgrading of surrounding area of the Lebyazhye Lake and it is done a filling work of coastline for making a place of resort for city residents.

The acid-alkali indicator of explored water kept with maximum allowable concentration (MAC) standards and surface water is characterized as neutral. The MAC of ammoniumnitrogen is normal in every water reservoir. But according to present quality's classification of natural water they are rated as "moderately contaminated" and are classified as the third quality's level.

It is educed an exceedence of nitrites $\left(\mathrm{NO}^{2-}\right)$ concerning the MAC 12.2-fold of the Lebyazhye Lake's sample, 2.4-fold the Poluy River's sample and the Shaytanka River's 
sample 1.9-fold. It is detected an exceedence of phosphates in researching samples of surface water from 17.5 till 20.0 according to the MAC. An exceedence of standards of the MAC of oil products is 10.5 in the Shaytanka River and 11.6 in the Lebyazhye Lake (Table 1). An increasing of phosphates' concentration in water always infracts a biological balance leading to process of water enrichment. The oil contamination of water body within the precincts of the city is a public problem involved with anthropogenic impact.

Table 1. Content of heavy metals and oil in surface water Salekhard $(\mathrm{mg} / \mathrm{l})$.

\begin{tabular}{|l|l|l|l|l|l|l|l|}
\hline Water body & $\mathrm{Mn}$ & $\mathrm{Fe}$ & $\mathrm{Cu}$ & $\mathrm{Zn}$ & $\mathrm{Pb}$ & $\mathrm{Ni}$ & $\mathrm{OP}$ \\
\hline Lake Lebyazhye & $\mathbf{0 . 0 7 2}$ & $\mathbf{0 . 6 1}$ & $\mathbf{0 . 0 0 2}$ & 0.006 & 0.0006 & 0.003 & $\mathbf{0 . 5 8}$ \\
\hline river Shaitanka & $\mathbf{0 . 4 2 9}$ & $\mathbf{2 . 7 8}$ & $\mathbf{0 . 0 0 1}$ & 0.004 & 0.0002 & 0.004 & $\mathbf{0 . 5 3}$ \\
\hline river Poluy & $\mathbf{0 . 2 9 5}$ & $\mathbf{7 . 9 1}$ & $\mathbf{0 . 0 0 4}$ & $\mathbf{0 . 0 2 3}$ & $\mathbf{0 . 0 0 6 3}$ & 0.006 & $\mathbf{0 . 5 5}$ \\
\hline $\begin{array}{l}\text { MAC of fishery } \\
\text { water bodies }\end{array}$ & 0.01 & 0.10 & 0.001 & 0.010 & 0.0060 & 0.010 & 0.05 \\
\hline $\begin{array}{l}\text { Average regional } \\
\text { values** }\end{array}$ & 0.019 & 0.80 & 0.0004 & 0.010 & 0.0015 & 0.003 & 0.01 \\
\hline $\begin{array}{l}\text { Background } \\
\text { values*** }\end{array}$ & 0.0067 & 0.416 & 0.0027 & 0.004 & 0.0003 & 0.0016 & \\
\hline
\end{tabular}

* - oil products

** - Medium local indicator of surface water of Cisuaralian region according to source

*** - Background indicators of lakes' water in Tundra and in Forest-Tundra by T.A. Kremlyeva.

The highest concentration's level of Mn is noticed in Shaytanka River (MAC is 40) and the lowest concentration's level is in the Lebyazhye Lake (MAC is 7.2). The Fe content is modified from $0.61 \mathrm{mg} / 1$ till $7.91 \mathrm{mg} / \mathrm{l}$ and a value's exceedence of MAC is from 6.1 till 27.8. An exceedence of background indicators is from 1.4 till 18 -fold.

The $\mathrm{Cu}$ concentration is modified from 0,06 till $0,023 \mathrm{mg} / \mathrm{l}$ and an exceedence of MAC is from 1.0 till 4.0, which is close to background indicators. The $\mathrm{Zn}$ concentration is modified from 0.004 till $0.023 \mathrm{mg} /$. According to MAC the $\mathrm{Zn}$ concentration is 2,3-fold higher in Poluy River. In other water reservoirs the $\mathrm{Zn}$ concentration is close to background indicators. The lead concentration is changed from 0.0002 till $0.0063 \mathrm{mg} / \mathrm{l}$. There is the highest concentration in the Poluy River and MAC is 1 . The Ni concentration is modified from 0.003 till $0.006 \mathrm{mg} / \mathrm{l}$. It is not gone beyond MAC, but it is close to regional indicator. The Cd concentration in water reservoir is not gone beyond MAC, but in Poluy River the background indicators of water reservoirs of Tundra's and Tundra - forests' are 1.4 -fold higher. The Mn, Ti, Va, Ba, Be concentration is not gone beyond the background indicators [4]. But the Al concentration is higher than MAC's indicators from 1.0 till 18.5-fold. But the high concentration of aluminum in involved the water environment is the natural factor [5].

There is a high concentration of $\mathrm{Mn}, \mathrm{Fe}$ and $\mathrm{Cu}$ in all discovered water reservoirs than it must be according to MAC. The high concentration of Fe in surface water is typical of Tundra's area. The Ni concentration is not gone beyond MAC, but it is close to medium regional indicators of surface water of Priuralsky area [4].

The water in discovered water reservoirs is characterized as not clean according to computed pollution index and relates to 4th level of quality.

In A.S. Krasnenko's working [6] are represented the discovering results of Shaytanka and Poluy rivers by means of bioindication methods. According to the discovering in 
compliance with TBI index the Poluy River is related to alpha- mesosaprobic (3-4 points) and to polysaprobic (1-2 points). EBI Index on the $1^{\text {st }}$ station has got 5 points, which means a low level of quality. EBI Index on other stations is only 2 points, which can be a bad quality of water. On this basis can be said the Poluy River's water is not drinkable without additional purification $[6,7,8]$.

According to TBI Index the Shaytanka River's water is related to alpha- mesosaprobic (3-4 points) on the $1^{\text {st }}$ station. As for other places the water's quality is related to polysaprobic (1-2 points). EBI Index of the $1^{\text {st }}$ section has 4 points, which is characterized as low quality. EBI Index of other sections is not higher 2 points, which is meant bad water's quality [6].

\section{Conclusion}

Surface water of discovered water reservoirs within the precincts of the Salekhard are characterized as neutral, low mineralized and they are not aligned with MAC according to oil-products, nitrites, phosphates and permanganate index. It is involved with high number of natural and anthropogenic origins.

In the surface waters of the Poluy River, there is an excess over the background levels of the Priuralsky region for a number of indicators: oil products, phosphates, nitrites, Mn, $\mathrm{Fe}, \mathrm{Cu}, \mathrm{Zn}, \mathrm{Pb}$. The content of pollutants and heavy metals is mainly determined by anthropogenic impact.

For the surface waters of the Shaytanka River and Lebyazhye Lake, excess over the background levels were revealed for the following indicators: oil products, nitrites, phosphates, $\mathrm{Mn}, \mathrm{Fe}$ and $\mathrm{Cu}$.

As a result of the study, it should be noted that all the studied water bodies belong to the 4th class of water quality and are characterized as "dirty". According to biondication indices, the water in the Poluy and Shaytanka Rivers has low quality.

Water bodies of urbanized areas are subject to a certain load, which affects the level of water pollution. The adjacent territory is also used for economic purposes. Currently, the area around Lebyazhye Lake is being refined for subsequent using for recreational purposes. The reservoirs and the adjacent territory are a resting place for city residents. To improve the ecological situation of water bodies, it is necessary to take measures aimed at reducing the negative impact on them.

\section{References}

1. Report on the environmental situation in the Yamal-Nenets Autonomus Okrug in 2019. (2020)

2. E. Shestakova, I. Fedorova, R. Loktev, R. Kolesnikov, N. Alexeeva, 18th International Multidisciplinary Scientific GeoConferences SGEM, 517-524 (2018)

3. Reference guide for the application of regional averages (Bratsk, 2014)

4. T.A. Kremleva, T.I. Moiseenko, V.Y. Khoroshavin, A.A. Shavnin, Bulletin of the Tyumen State University, 12, 80-89 (2012)

5. Quality standards for water bodies of fishery significance, including standards for maximum permissible concentrations of harmful substances in the waters of water bodies of fishery significance.

6. E.V. Agbalyan, R.A. Kolesnikov, A.S. Krasnenko, E.N. Morgun, E.V. Shinkaruk, A.S. Pechkin, R.I. Loktev, R.M. Ilyasov, V.O. Kobelev, Water management of Russia, 6, 623 (2019) 
7. A.S. Krasnenko, A.S. Pechkin, Y.A. Pechkina, National Association of Scientists (NAU), 11 (16), 150-152 (2015)

8. Ecosystem of a small river in changing environmental conditions (Gidrometeoizdat, Leningrad, 2007)

9. V.A. Abakumov, Scientific foundations of surface water quality control by hydrobiological indicators (Gidrometeoizdat, Leningrad, 1977) 